\title{
PERTUMBUHAN DAN PRODUKSI MENTIMUN (Cucumis sativus L.) AKIBAT PEMBERIAN MACAM DAN DOSIS PUPUK KANDANG
}

\section{GROWTH AND PRODUCTION OF CUCUMBER (Cucumis Sativus L.) DUE TO THE TYPE AND DOSAGE OF CAGE FERTILIZER}

\author{
Junaidi $^{1}$, Supandji ${ }^{2}$, Nugraheni Hadiyanti ${ }^{3}$ \\ ${ }^{123}$ Fakultas Pertanian Universitas Kadiri Kediri \\ Email:nugraheni@unik-kediri.ac.id
}

Article Submitted : 06-10-2021

Article Accepted : 22-12-2021

\begin{abstract}
Cucumber is one of the important vegetable commodities that have high nutritional value and is alternative medicine. To increase the productivity of both plants and the land where plants are grown, organic fertilization is needed. Manure is an organic fertilizer to increase soil fertility so that plant growth increases. Giving different types of manure with different doses will result in different plant growth and development. The purpose of this study was to determine the effect of the interaction between the type and dose of manure treatment on the growth and production of cucumbers. This study is a factorial experiment with two factors, which were arranged according to a completely randomized design (CRD) and repeated 3 (three) times. The first factor is the type of manure consisting of 3 levels, namely: chicken manure (K1), cow manure (K2), and goat manure (K3). The second factor is the dose of manure which consists of 3 levels, namely: 10 tons/ha (D1), 15 tons/ha (D2), and 20 tons/ha (D3). Observational data were analyzed by analysis of variance to determine the effect of the treatment on the observed parameters. After knowing the effect of treatment on the observed parameters, it is continued with the Least Significant Difference (BNT) test at the 5\% level if it is significantly different. The combination of types and doses of manure significantly affected plant height, number, and leaf area at the age of observation 21 and 28 DAP, number of fruits, and fruit production per plant. The combination of the type of manure and the dose of manures did not significantly affect the number of leaves at 14 days of age, fruit length, fruit diameter, and fruit weight. The combination of goat manure at a dose of 20 tons/ha resulted in the best growth and production of cucumbers.
\end{abstract}

Kata kunci: cucumber, dose, manure, production

\section{PENDAHULUAN}

Mentimun (Cucumis sativus L.) dikenal sebagai tanaman semusim yang bersifat merambat dan termasuk salah satu sayuran dari keluarga labulabuan (Cucurbitaceae). Tanaman mentimun merupakan komoditas sayuran buah yang banyak dibudidayakan oleh petani. Pada umumnya masyarakat Indonesia mengkonsumsi sayur atau buah mentimun langsung dalam bentuk segar maupun olahan lainnya. Dalam pengusahaannya, budidaya tanaman mentimun relatif mudah, menguntungkan dan butuh waktu yang tidak terlalu lama untuk dapat memetik hasilnya (Yefriwati \& Delvira, 2021).

Buah mentimun mengandung gizi cukup tinggi bagi kesehatan dan menambah cita rasa makan. Selain itu, mentimun juga dimanfaatkan untuk kecantikan, dan mengobati beberapa jenis penyakit. (Amin, 2015). Buah mentimun mengandung lemak, protein, vitamin $\mathrm{A}, \mathrm{B} 1$, dan $\mathrm{C}$, serta mengandung mineral seperti besi, fosfor kalsium, belerang. Mentimun mentah dapat meningkatkan stamina dan menurunkan panas badan. Buah mentimun berkhasiat menekan gula darah, menetralkan racun, menurunkan kolesterol dan kandungan seratnya tinggi sehingga mudah dicerna dan melancarkan buang air besar. (Moekasan et al., 2014).

Kebutuhan komoditas mentimun dari tahun le tahun mengalami peningkatan tetapi dalam kurun waktu tertentu produksinya mengalami penurunan. Pada tahun 2014, 2015 dan 2016 produksi mentimun masing-masing sebesar 477.976; 447.677 dan 430.201 ton. Kebutuhan buah mentimun terus meningkat karena kesadaran pentingnya sayuran bagi kesehatan sehingga permintaan terus meningkat (Badan Pusat Statistik, 2016).

Peningkatan produksi tanaman adalah dengan meningkatkan kesuburan tanah sebagai media tanam melalui pemupukan (Sari et al., 2017). Dalam ilmu bercocok tanam, nenek moyang telah menerapkan prinsip pemupukan organik. Pada saat itu kegiatan bercocok tanam masih secara tradisional menggunakan bahan-bahan alamiah. Pemupukan dengan bahan organik penting dilakukan karena dalam perkembangannya ternyata banyak permasalahan akibat penggunaan pupuk dan pesttisida kimia. Dampak dari penggunaan pupuk dan pestisida kimia secara berlebihan adalah dihasilkannya produk pertanian yang tercemar 
bahan kimia dan pencemaran lingkungan (Supandji \& Junaidi, 2020).

Dalam budidaya tanaman penggunaan pupuk organik diperlukan untuk meningkatkan produksi tanaman karena meningkatnya kesuburan tanah, meningkatkan kualitas lahan secara berkelanjutan mengurangi pencemaran lingkungan (Putra et al., 2020). Pupuk kandang merupakan salah satu pupuk organik yang mudah ditemukan dan mudah pembuatannya. Penggunaan pupuk kandang dapat menambah bahan organik dalam tanah sehingga tanah menjadi gembur dan subur. Usaha penambahan bahan organik dalam tanah akan memperbaiki sifat kimia, biologi dan fisik tanah (Safitri et al., 2017). Penggunaan pupuk bokashi pada tanaman akan meningkatkan kesuburan tanah baik fisik, kimiawi maupun biologi sehingga pertumbuhan dan produksi tanaman meningkat (Junaidi \& Djoko, 2021).

Pupuk kandang yang umumnya digunakan adalah pupuk kandang sapi, pupuk kandang kambing, dan pupuk kandang ayam. Unsur hara yang terkandung pada masing-masing pupuk kandang tidaklah sama sehingga memberikan pengaruh yang berbeda pula terhadap tanaman. Jumlah unsur hara yang terkandung didalam masing-masing pupuk kandang tersebut akan berpengaruh terhadap dosis pupuk yang harus diberikan pada suatu tanaman agar menghasilkan produksi yang tinggi. Berdasarkan hal tersebut perlu adanya penelitian untuk mengetahui pengaruh interaksi antara macam dan dosis pupuk kandang terhadap pertumbuhan dan produksi tanaman mentimun.

\section{BAHAN DAN METODE}

Penelitian telah dilaksanakan di Desa Sumberkepuh, Kecamatan Ngronggot, Kabupaten Nganjuk, Propinsi Jawa Timur dengan ketinggian tempat \pm 56 meter dari permukaan laut. Waktu penelitian pada bulan Mei sampai dengan Juli 2021. Bahan dan alat yang digunakan dalam penelitian adalah benih unggul mentimun varietas tirta F1, pupuk kandang ayam, pupuk kandang sapi, pupuk kandang kambing, polybag, cangkul, timbangan, penggaris, rafia, gembor, ajir.

Penelitian ini merupakan percobaan faktorial 2 faktor dengan menggunakan Rancangan Acak Lengkap (RAL). Faktor pertama adalah macam pupuk kandang yang terdiri dari 3 level yaitu: pupuk kandang ayam (K1), pupuk kandang sapi (K2), pupuk kandang kambing (K3). Faktor kedua adalah dosis pupuk kandang terdiri 3 level yaitu: 10 ton $/$ hektar $=1,0 \mathrm{~kg}$ per polybag (D1), 15 ton $/$ hektar $=1,5 \mathrm{~kg}$ per polybag (D2), 20 ton $/$ hektar $=2,0 \mathrm{~kg}$ per polybag (D3). Dari kedua faktor diperoleh 9 kombinasi perlakuan dengan pengulangan sebanyak 3 kali.

Pelaksanaan penelitian meliputi: persiapan media tanam, penanaman, penyiraman, penyiangan, dan wiwil dan pemasangan ajir. Persiapan media tanam adalah mengambil tanah dari sawah kemudian dicampur dengan pupuk kandang ayam, sapi dan kambing sesuai perlakuan. Campuran tanah dan macam pupuk kandang dimasukkan ke dalam polybag sampai dua pertiga bagian. Stelah itu polybag disiram sampai jenuh dan dibiarkan selama 25 jam. Penanaman benih mentimun varietas tirta $F 1$ ke dalam polybag yang berisi media tanam \pm kedalaman $3 \mathrm{~cm}$ dan ditutup dengan tanah tipis-tipis.

Penyiraman dilakukan sebanyak satu kali dalam sehari yang dilakukan pada siang hari atau sore hari. Penyiraman bertujuan untuk memelihara suhu dan kelembapan tanah pada media tanam. Penyiangan dilakukan jika didalam media tanam tumbuh gulma yang akan mengganggu pertumbuhan tanaman mentimun. Wiwil adalah menghilangkan cabang-cabang yang tumbuh pada batang utama. Wiwil dilakukan jika pada batang utama telah tumbuh cabang yang panjangnya sekitar $10 \mathrm{~cm}$. Pemasangan ajir dilakukan jika tanaman sudah menunjukkan tanda-tanda akan membentuk sulur, sehingga tanaman dapat merambat pada ajir. Pemasangan ajir ini bertujuan untuk mempermudah perawatan dan pemeliharaan tanaman mentimun. Panen mentimun dilakukan secara bertahap, panen pertama saat tanaman berumur sekitar 75 hari, yaitu bila buah mentimun sudah memenuhi kriteria panen (diameter buah mentimun kurang lebih $5 \mathrm{~cm}$ ).

Pengamatan dilakukan pada saat tanaman mulai berumur dua minggu dan interval waktu pengamatan adalah tujuh hari. Parameter yang diamati meliputi parameter pertumbuhan dan produksi tanaman mentimun. Parameter pertumbuhan yang diamati meliputi: tinggi tanaman (cm) yang diukur mulai permukaan tanah hingga titik tumbuh tertinggi, jumlah daun (helai) dengan menghitung daun yang membuka sempurna, luas daun diukur menggunakan rumus konstanta. Parameter produksi yang diamati meliputi: jumlah buah pertanaman dihitung semua buah yang di panen pertama sampai panen terakhir pada tiap-tiap tanaman, diameter buah yaitu dengan mengukur keliling buah mentimun menggunakan rafia kemudian dihitung diameter buahnya, panjang buah diukur mulai pangkal sampai ujung buah, berat buah pertanaman, ditimbang buah yang dipanen pertanaman.

\section{HASIL DAN PEMBAHASAN}

\section{a. Tinggi Tanaman}

Hasil analisis ragam menunjukkan adanya pengaruh interaksi antara perlakuan macam dan dosis pupuk kandang terhadap tinggi tanaman pada umur 14, 21, maupun 28 HST. 
Tabel 1. Pengaruh interaksi perlakuan macam dan dosis pupuk kandang terhadap tinggi tanaman mentimun pada umur 14,21 , dan 28 HST

\begin{tabular}{cccc}
\hline \multirow{2}{*}{ Perlakuan } & \multicolumn{4}{c}{ Tinggi tanaman $(\mathrm{cm})$ pada umur } \\
& $14 \mathrm{HST}$ & $21 \mathrm{HST}$ & $28 \mathrm{HST}$ \\
\hline K1D1 & $10,83 \mathrm{a}$ & $40,33 \mathrm{ab}$ & $180,00 \mathrm{a}$ \\
K1D2 & $12,00 \mathrm{ab}$ & $46,33 \mathrm{a}$ & $184,33 \mathrm{ab}$ \\
K1D3 & $14,17 \mathrm{bc}$ & $48,33 \mathrm{bc}$ & $188,33 \mathrm{ab}$ \\
K2D1 & $10,33 \mathrm{a}$ & $41,00 \mathrm{a}$ & $183,33 \mathrm{ab}$ \\
K2D2 & $12,33 \mathrm{ab}$ & $47,00 \mathrm{ab}$ & $190,00 \mathrm{bc}$ \\
K2D3 & $13,67 \mathrm{bc}$ & $47,67 \mathrm{ab}$ & $206,00 \mathrm{bc}$ \\
K3D1 & $14,33 \mathrm{bc}$ & $49,67 \mathrm{bc}$ & $191,67 \mathrm{bc}$ \\
K3D2 & $16,67 \mathrm{~cd}$ & $53,00 \mathrm{bc}$ & $213,33 \mathrm{bc}$ \\
K3D3 & $18,00 \mathrm{~d}$ & $59,33 \mathrm{c}$ & $226,67 \mathrm{c}$ \\
\hline
\end{tabular}

Keterangan: Angka-angka yang diikuti huruf yang sama pada kolom yang sama tidak berbeda nyata pada uji BNT 5\%

Berdasarkan tabel 1 dapat diketahui bahwa kombinasi perlakuan macam pupuk kandang kambing dengan dosis 20 ton/ha (K3D3) menghasilkan tanaman tertinggi, sedangkan tanaman terpendek dihasilkan oleh kombinasi perlakuan macam pupuk kandang ayam dengan dosis 10 ton/ha (K1D1). Pupuk kandang kambing dengan dosis 20 ton/ha menghasilkan tanaman tertinggi karena kondisi tanah semakin baik bagi pertumbuhan tanaman mentimun sehingga tanaman yang dihasilkan semakin panjang.

Pupuk kandang terdiri dari kotoran hewan (padat dan cair), ditambah dengan sisa-sisa makanannya. Struktur pupuk kandang kambing lebih baik dari pada struktur pupuk kandang ayam dan sapi. Pupuk kandang ayam terlalu lembut dan kurang gembur karena kurang mengandung serat. Pupuk kandang sapi terlalu kasar, karena terlalu banyak mengandung serat sisa-sisa tanaman yang dimakan. Pupuk kandang kambing terdiri dari kotoran yang tidak mengandung serat dan sisa-sisa makanan yang banyak mengandung serat, sehingga strukturnya lebih baik dari pada pupuk kandang ayam dan sapi. Kandungan unsur nitrogen pada pupuk kandang kambing lebih banyak dibanding dengan pupuk kandang ayam dan sapi (Agustina, 2011). Pupuk kandang kambing dengan dosis 20 ton/ha (K3D3) menghasilkan tanaman tinggi pada umur 14, 21 dan 28 HST masing-masing sebesar 18,$00 ; 59,33$ dan $226,67 \mathrm{~cm}$.

\section{b. Jumlah Daun}

Berdasarkan analisis ragam perlakuan macam dan dosis pupuk kandang tidak berpengaruh terhadap jumlah daun tanaman mentimun pada umur pengamatan 14 hari, akan tetapi menunjukkan pengaruh nyata pada umur pengamatan 21 dan 28 HST.

Tabel 2. Pengaruh interaksi perlakuan macam dan dosis pupuk kandang terhadap jumlah daun tanaman mentimun pada umur 14 , 21, dan 28 HST

\begin{tabular}{|c|c|c|c|}
\hline \multirow{2}{*}{ Perlakuan } & \multicolumn{3}{|c|}{ Jumlah daun (helai) pada umur } \\
\hline & $14 \mathrm{HST}$ & $21 \mathrm{HST}$ & $28 \mathrm{HST}$ \\
\hline K1D1 & $2,67 \mathrm{a}$ & $5,33 \mathrm{a}$ & $12,67 \mathrm{a}$ \\
\hline K1D2 & $2,33 \mathrm{a}$ & $6,67 \mathrm{ab}$ & $13,33 \mathrm{ab}$ \\
\hline K1D3 & $2,67 \mathrm{a}$ & $7,00 \mathrm{bc}$ & $15,00 \mathrm{bc}$ \\
\hline K2D1 & $2,33 \mathrm{a}$ & $6,00 \mathrm{a}$ & $14,00 \mathrm{~b}$ \\
\hline K2D2 & 2,67 a & $7,30 \mathrm{bc}$ & $16,33 \mathrm{c}$ \\
\hline K2D3 & $2,67 \mathrm{a}$ & $8,67 \mathrm{~cd}$ & $17,67 \mathrm{c}$ \\
\hline K3D1 & $2,33 \mathrm{a}$ & $8,00 \mathrm{bc}$ & $14,67 \mathrm{~b}$ \\
\hline K3D2 & $2,33 \mathrm{a}$ & $9,33 \mathrm{~cd}$ & $18,67 \mathrm{~cd}$ \\
\hline K3D3 & $3,00 \mathrm{a}$ & $9,67 \mathrm{~d}$ & $19,33 \mathrm{~d}$ \\
\hline
\end{tabular}

Keterangan: Angka-angka yang diikuti huruf yang sama pada kolom yang sama tidak berbeda nyata pada uji BNT 5\%

Perlakuan macam dan dosis pupuk kandang pada umur pengamatan 14 HST tidak menunjukkan perbedaan yang nyata karena tanaman masih cukup kecil, jumlah daunnya masih sekitar 2 sampai 3 helai, tinggi tanaman masih sekitar 10-18 cm sehingga pengaruh yang ditimbulkannya belum tampak nyata perbedaannya.

Pengaruh interaksi perlakuan macam dan dosis pupuk kandang baru terlihat pada saat tanaman sudah berumur 21 HST. Hal ini dimungkinkan karena tanaman sudah cukup besar sehingga terlihat perbedaannya. Jumlah daun terbanyak dihasilkan oleh kombinasi perlakuan pupuk kandang kambing dengan dosis 20 ton/ha (K3D3) yaitu 9,67 helai pada umur 3 minggu dan 19,33 pada umur 28 HST. Struktur pupuk kandang lebih baik dari pada pupuk kandang sapi dan ayam. Kandungan unsur nitrogen pada kotoran kambing (padat dan cair) lebih banyak bila dibandingkan dengan kotoran sapi dan ayam (Agustina, 2011). Semakin banyak dosis pupuk kandang yang diberikan kedalam tanah, maka akan semakin banyak unsur nitrogen yang masuk dalam tanah. Daun sebagai organ tanaman yang berfungsi sebagai tempay sintesis makanan untuk kebutuhan tanaman maupun sebagai cadangan makanan. Daun memiliki klorofil yang berperan dalam proses fotosintesis. Jumlah daun yang terbentuk semakin banyak berpotensi meningkatkan laju fotosintesis (Duaja, 2012).

\section{c. Luas Daun}

Hasil analisis ragam menunjukkan pengaruh kombinasi perlakuan macam dan dosis pupuk kandang terhadap luas daun tanaman mentimunpada pengamatan 21 dan 28 HST sedangkan pengamatan 14 HST tidak berbeda nyata.

Tabel 3. Pengaruh interaksi perlakuan macam dan dosis pupuk kandang terhadap luas daun tanaman mentimun pada umur 14,21 , dan 28 HST

\begin{tabular}{cccc}
\hline \multirow{2}{*}{ Perlakuan } & \multicolumn{3}{c}{ Luas daun $\left(\mathrm{cm}^{2}\right)$ pada umur } \\
\cline { 2 - 4 } & $14 \mathrm{HST}$ & $21 \mathrm{HST}$ & $28 \mathrm{HST}$ \\
\hline K1D1 & $154,21 \mathrm{a}$ & $279,39 \mathrm{a}$ & $646,17 \mathrm{a}$ \\
K1D2 & $211,14 \mathrm{a}$ & $318,63 \mathrm{ab}$ & $663,00 \mathrm{a}$ \\
K1D3 & $216,68 \mathrm{a}$ & $344,78 \mathrm{~b}$ & $710.84 \mathrm{~cd}$
\end{tabular}




\begin{tabular}{llll} 
K2D1 & $185,94 \mathrm{a}$ & $337,65 \mathrm{~b}$ & $679,83 \mathrm{ab}$ \\
K2D2 & $213,25 \mathrm{a}$ & $344,98 \mathrm{~b}$ & $693,16 \mathrm{bc}$ \\
K2D3 & $217,95 \mathrm{a}$ & $355,42 \mathrm{bc}$ & $748,17 \mathrm{~cd}$ \\
K3D1 & $195,26 \mathrm{a}$ & $353,61 \mathrm{bc}$ & $697,17 \mathrm{bc}$ \\
K3D2 & $234,05 \mathrm{a}$ & $465,16 \mathrm{~cd}$ & $765,00 \mathrm{~cd}$ \\
K3D3 & $257,04 \mathrm{a}$ & $496,34 \mathrm{~d}$ & $781.83 \mathrm{~d}$ \\
\hline
\end{tabular}

Keterangan: Angka-angka yang diikuti huruf yang sama pada kolom yang sama tidak berbeda nyata pada uji BNT 5\%

Perlakuan macam dan dosis pupuk kandang belum berpengaruh nyata terhadap luas daun tanaman mentimun pada pengamatan 14 HST. Hal ini kemungkinan karena pada umur pengamatan 14 HST, tanaman masih relatip kecil sehingga daun yang terbentuk belum ada perbedaan. Dengan meningkatnya umur tanaman, daun yang terbentuk semakin besar dan luas sehingga terlihat perbedaan yang nyata. Luas daun yang tertinggi dihasilkan oleh kombinasi pupuk kandang dengan dosis yang tertinggi yaitu 20 ton/ha baik pada pupuk kandang ayam, sapi maupun kambing, sedangkan luas daun terendah dihasilkan oleh perlakuam dosis terendah yaitu 10 ton/ha.

Kombinasi perlakuan yang menghasilkan luas daun tertinggi adalah pupuk kandang kambing dengan dosis 20 ton/ha karena kombinasi perlakuan ini menghasilkan pertumbuhan tanaman yang paling baik, jumlah daun yang dihasilkan paling banyak. Luas daun yang dihasilkan oleh kombinasi perlakuan pupuk kandang kambing dengan dosis 20 ton/ha (K3D3) pada pengamatan 21 HST sebesar $496,34 \mathrm{~cm}^{2}$ sedangkan pengamatan 28 HST sebesar $781,83 \mathrm{~cm}^{2}$.

\section{d. Diameter, Panjang, dan Berat Buah}

Berdasarkan analisis ragam perlakuan macam dan dosis pupuk kandang tidak menunjukkan interaksi terhadap diameter buah, panjang buah, dan berat buah tanaman mentimun. Masing-masing perlakuan juga tidak menunjukkan pengaruh yang nyata.

Tabel 4. Pengaruh interaksi perlakuan macam dan dosis pupuk kandang terhadap diameter buah, panjang buah berat buah mentimun pada saat panen

\begin{tabular}{cccc}
\hline Perlakuan & $\begin{array}{c}\text { Diameter } \\
\text { Buah }(\mathrm{cm})\end{array}$ & $\begin{array}{c}\text { Panjang } \\
\text { Buah } \\
(\mathrm{cm})\end{array}$ & $\begin{array}{c}\text { Berat } \\
\text { Buah }(\mathrm{gr})\end{array}$ \\
\hline K1 & 18,17 & 22,72 & 383,22 \\
K2 & 18,44 & 23,17 & 393,89 \\
K3 & 19,11 & 23,45 & 409,11 \\
\hline & $\mathrm{ns}$ & $\mathrm{ns}$ & $\mathrm{ns}$ \\
\hline D1 & 17,89 & 22,50 & 382,11 \\
D2 & 18,72 & 22,89 & 393,11 \\
D3 & 19,11 & 23,95 & 411,00 \\
\hline & $\mathrm{ns}$ & $\mathrm{ns}$ & $\mathrm{ns}$ \\
\hline
\end{tabular}

Keterangan: Angka-angka yang diikuti huruf yang sama pada kolom yang sama tidak berbeda nyata pada uji BNT 5\%
Tabel 4 menunjukkan bahwa perlakuan macam dan dosis pupuk kandang tidak berpengaruh nyata terhadap diameter buah, panjang buah, dan berat buah mentimun. Hal ini berarti bahwa diameter buah, panjang buah, dan berat buah lebih dipengaruhi oleh faktor genetis dari pada pengaruh perbaikan kesuburan tanah melalui pemberian macam-macam pupuk kandang dan dosis pupuk kandang.

Pada perlakuan pemberian pupuk kandang kambing menghasilkan buah mentimun lebih besar diameternya, lebih panjang buahnya, dan lebih berat bila dibandingkan dengan pemberian pupuk kandang sapi dan ayam walaupun tidak sampai menunjukan perbedaan yang nyata. Pada perlakuan dosis pupuk kandang, semakin tinggi dosis pupuk kandangnya menghasilkan buah mentimun semakin besar diameternya, semakin panjang buahnya, dan semakin berat buahnya walaupun tidak sampai menunjukan perbedaan yang nyata. Bobot segar suatu tanaman dapat menunjukkan aktivitas metabolisme tanaman dan nilai bobot tanaman dipengaruhi oleh unsur hara, hasil metabolism dan kandungan air dalam jaringan (Aisyah et al., 2011). Semakin kecil biomassa yang dihasilkan memungkinkan pengurangan proses metabolisme tanaman dan sebaliknya semakin berat bobot tanaman, proses metabolisme dalam tanaman semakin baik (Karamina et al., 2020).

\section{e. Jumlah Buah dan Produksi per Tanaman}

Hasil analisis ragam menunjukkan bahwa terjadi pengaruh interaksi yang nyata antara perlakuan macam pupuk kandang dan dosis terhadap jumlah buah dan produksi buah pertanaman. Hasil uji Ducan;s pengaruh interaksi antara macam pupuk kandang dan dosis terhadap jumlah buah dan poduksi buah tertera pada tabel 4.5 .

Tabel 5. Pengaruh interaksi perlakuan macam dan dosis pupuk kandang terhadap jumlah buah dan produksi per tanaman mentimun pada saat panen

\begin{tabular}{ccc}
\hline Perlakuan & Jumlah Buah & $\begin{array}{c}\text { Produksi Per } \\
\text { tanaman }(\mathrm{gr})\end{array}$ \\
\hline K1D1 & $6,00 \mathrm{a}$ & $2214,34 \mathrm{a}$ \\
K1D2 & $10,33 \mathrm{ab}$ & $3824,53 \mathrm{a}$ \\
K1D3 & $13,00 \mathrm{c}$ & $52210,00 \mathrm{~b}$ \\
K2D1 & $8,00 \mathrm{ab}$ & $3064,63 \mathrm{a}$ \\
K2D2 & $12,67 \mathrm{c}$ & $4979,34 \mathrm{ab}$ \\
K2D3 & $17,33 \mathrm{~d}$ & $7018,65 \mathrm{c}$ \\
K3D1 & $8,67 \mathrm{ab}$ & $3415,98 \mathrm{a}$ \\
K3D2 & $19,67 \mathrm{de}$ & $7986,02 \mathrm{~cd}$ \\
K3D3 & $23,00 \mathrm{e}$ & $9961,91 \mathrm{~d}$ \\
\hline
\end{tabular}

Keterangan: Angka-angka yang diikuti huruf yang sama pada kolom yang sama tidak berbeda nyata pada uji BNT 5\%

Tabel 4.5 menunjukan bahwa kombinasi perlakuan macam pupuk kandang kambing dan 
dosis 20 ton/ha (K3D3) menghasilkan jumlah buah paling banyak dan berat produksi pertanaman paling tinggi walaupun tidak berbeda dengan kombinasi perlakuan macam pupuk kandang kambing dengan dosis 15 ton/ha (K3D2). Kombinasi perlakuan macam dosis pupuk kandang kambing dengan dosis 20 toh/ha menyebabkan keadaan tanah tempat tumbuh tanaman menjadi lebih baik, sehingga pertumbuhan tanaman mentimun menjadi lebih baik, menghasilkan jumlah daun paling banyak dan luas daun paling besar. Daun merupakan tempat terjadinya proses fotosintesis. Semakin tinggi luas daun, berarti semakin tinggi laju fotosintesis, sehingga proses pertumbuhan bunga dan buah menjadi lebih baik, akhirnya jumlah buah yang dihasilkan lebih banyak, dan produksi pertanaman lebih tinggi. Jumlah buah dan berat produksi pertanaman yang dihasilan kombinasi perlakuan K3D3 adalah 23 biji dan 9961,91 gram.

\section{KESIMPULAN}

Interaksi perlakuan macam dan dosis pupuk kandang berpengaruh terhadap tinggi tanaman pada semua umur pengamatan, jumlah dan luas daun pada pengamatan 21 dan $28 \mathrm{HST}$, jumlah buah dan produksi buah pertanaman. Perlakuan macam dan dosis pupuk kandang tidak berpengaruh nyata terhadap jumlah daun pada pengamtan 14 HST, panjang buah, diameter buah, dan berat buah tanaman mentimun. Kombinasi perlakuan pupuk kandang kambing dengan dosis 20 ton/ha menghasilkan pertumbuhan dan produksi mentimun paling baik.

\section{UCAPAN TERIMA KASIH}

Penulis mengucapkan terima kasih kepada LP3M Universitas Kadiri yang telah mendukung pembiayaan dalam kegiatan ini dan teman sejawat Dosen-dosen Fakultas Pertanian Universitas Kadiri atas masukan dan saran saat penelitian dan penyusunan naskah jurnal.

\section{DAFTAR PUSTAKA}

Agustina. (2011). Teknologi Hijau dalam Pertanian Organik Menuju Pertanian Berlanjut. Universitas Brawijaya Press.

Aisyah, S., Sunarlim, N., \& Solfan, B. (2011). Pengaruh Urine Sapi Terfermentasi dengan Dosis dan Interval Pemberian yang Berbeda terhadap Pertumbuhan Tanaman Sawi (Brassica juncea L.). Jurnal Agroteknologi.

Amin, A. R. (2015). Mengenal Budidaya Tanaman Mentimun Melalui Pemanfaatan Media Informasi. Jupiter.

Badan Pusat Statistik. (2016). Produksi sayuran di Indonesia. Badan Pusat Statistik Nasional.
Jakarta.

Duaja, M. D. (2012). Pengaruh Bahan Dan Dosis Kompos Cair Terhadap Pertumbuhan Selada (Lactuca sativa sp.). Bioplantae.

Junaidi, \& Djoko, R. (2021). UpayaOptimalisasiHasil Panen Padi MenggunakanBerbagai Model Jarak Tanam Dan Dosis Pupuk Kandang. Agrinika, 5(1), 84-94.

https://doi.org/http://dx.doi.org/10.30737/agri nika.v5i1.1554

Karamina, H., Indawan, E., Murti, A. T., \& Mujoko, T. (2020). Respons pertumbuhan dan hasil tanaman mentimun terhadap aplikasi pupuk NPK dan pupuk organik cair kaya fosfat.

Kultivasi.

https://doi.org/10.24198/kultivasi.v19i2.26316

Moekasan, T., Prabaningrum, L., Yoga, W. A., \& Putter, H. de. (2014). Panduan Praktis Budidaya Mentimun. Penebar Swadaya.

Putra, R. D., Jafrizal, J., \& Suryadi, S. (2020). PENGARUH JARAK TANAM DAN JENIS PUPUK KANDANG TERHADAP PERTUMBUHAN DAN HASIL TANAMAN JAGUNG MANIS (ZeaMays Saccharata Sturt.). Agriculture. https://doi.org/10.36085/agrotek.v14i2.1025

Safitri, M. D., Hendarto, K., Hidayat, K. F., \& Sunyoto. (2017). Pengaruh Dosis Pupuk Kandang Kambing dan Pupuk Hayati terhadap Pertumbuhan dan Hasil Jagung (Zea mays L.). J. Agrotek Tropika.

Sari, M. N., Sudarsono, \& Darmawan. (2017). Pengaruh Bahan Organik Terhadap Ketersediaan Fosfor pada Tanah-Tanah Kaya $\mathrm{Al}$ dan Fe. Buletin Tanah Dan Lahan.

Sumpena, U. (2002). Budidaya Mentimun. Penebar Swadaya.

Supandji, S., \& Junaidi, J. (2020). PENGARUH PUPUK UREA DAN PUPUK ORGANIK SAPI TERHADAP PERTUMBUHAN DAN PRODUKSI TANAMAN PADI VARIETAS IR. 64 (Oryza sativa L). Jurnal Agrinika: Jurnal Agroteknologi Dan Agribisnis. https://doi.org/10.30737/agrinika.v3i2.727

Yefriwati, Y., \& Delvira, Z. (2021). PENGGUNAAN PUPUK ORGANIK TABUR (POT) DAN ZEOLIT UNTUK MENINGKATKAN PERTUMBUHANDAN HASIL TANAMAN MENTIMUN (Cucumis $\begin{array}{lll}\text { sativus } & \text { L.)DI } & \text { PT.INDMIRA }\end{array}$ YOGYAKARTA. HORTUSCOLER. https://doi.org/10.32530/jh.v2i01.380 